\title{
PENGGUNAAN PAKAN BUATAN BERBASIS MAGGOT DAN LEMNA MINOR PADA POKDAKAN DI KOTA PEKALONGAN
}

\author{
Beny Diah Madusari ${ }^{1 *}$, Sajuri ${ }^{2}$, Dwi Edi Wibowo ${ }^{3}$, Marlinda Irawati ${ }^{4}$ \\ ${ }^{1}$ Program Studi Budidaya Perairan, Fakultas Perikanan,Universitas Pekalongan \\ J1. Sriwijaya No.3, Bendan, Kec. Pekalongan Bar., Kota Pekalongan, Jawa Tengah 51119 \\ ${ }^{2}$ Program Studi Agroteknologi, Fakultas Pertanian,Universitas Pekalongan \\ Jl. Sriwijaya No.3, Bendan, Kec. Pekalongan Bar., Kota Pekalongan, Jawa Tengah 51119 \\ ${ }^{3}$ Program Studi Hukum, Fakultas Hukum,Universitas Pekalongan \\ J1. Sriwijaya No.3, Bendan, Kec. Pekalongan Bar., Kota Pekalongan, Jawa Tengah 51119 \\ ${ }^{4}$ Sekolah Tinggi Ilmu Komunikasi Inter Studi \\ Jl.Kapten Tendean No. 2. Kebayoran Baru, Jakarta Selatan \\ "Email: bennydiah@gmail.com
}

\begin{abstract}
Abstrak
Budidaya lele oleh pokdakan (kelompok bididaya ikan) di kota pekalongan mengalami kendala dalam penyediaan pakan buatan karena makin mahal melalui penerapan teknologi tepat guna maka dilakukan dan demplot pembuatan pakan buatan dengan memanfaatkan limbah/ gulma air yakni lemna minor dan maggot. Maggot dapat diproduksi secara mudah dan cepat, mengandung protein sebesar 40-50\%, dan memanfaatkan limbah organik sebagai sumber makanannya. Kandungan protein kasar dari Lemna minor adalah 37,6\% dan serat yang relatif rendah yakni 9,3\%. Untuk mendapatkan pertumbuhan ikan yang optimum, perlu ditambahkan pakan tambahan yang berkualitas tinggi, yaitu pakan yang memenuhi kebutuhan nutrisi ikan. Metode penerapan teknologi tepat guna dengan penyuluhan, pelatihan dan demplot, aplikasi. Alat yang digunakan adalah penepung model FFC15, pembuat pellet model MPT0010 dan pengering rakitan menggunakan gas. Hasil penerapan yakni anggota KUB lele mandiri dan KUB lestari $85 \%$ dapat membuat pakan buatan dengan pakan yang memiliki kandungan protein $30 \%$.
\end{abstract}

\section{Kata kunci: pokdakan, Maggot, Lemna minor, pellet}

\section{Pendahuluan}

Pokdakan Budidaya Lele merupakan kelompok yang selalu menggunakan pakan ikan (pellet) dalam proses budidaya ikan lele. Saat ini dalam pemenuhan kebutuhan pakan, banyak pokdakan sedikit menggunakan pakan pabrikan namun membuat pakan sendiri dikarenakan harga pakan ikan / pellet semakin mahal. Dan KUB Pakan Ikan Mandiri. "Lestari" sebagai kelompok yang memproduksi pakan buatan juga mengalami kendala dalam penyediaan tepung ikan karena makin makah dan ketersediaan tergantung iklim laut. Tepung ikan adalah bahan baku utama dalam pembuatan pakan buatan, sehingga pengganti tepung ikan sangat diperlukan untuk memperoleh produk pakan buatan yang murah namun kandungan protein sekitar $30 \%$.

Alternatif pengganti tepung ikan dan ketersediaan yang terus menerus adalah harapan dari pengusaha pakan ikan dan harga pakan yang murah dan baik adalah harapan dari pembudidaya ikan lele. Banyak usaha yang dapat dilakukan untuk mengurangi biaya produksi pakan, namun belum tentu dapat menjaga kualitas dari pakan. Pembuatan pakan pellet memerlukan beberapa bahan yang dicampurkan. Pelet adalah bentuk makanan buatan yang dibuat dari beberapa macam bahan yang kita ramu dan kita jadikan adonan, kemudian kita cetak sehingga merupakan batangan atau bulatan kecil-kecil. Ukurannya berkisar antara 1-2 cm. Jadi pelet tidak berupa tepung, tidak berupa butiran, dan tidak pula berupa larutan (Setyono, 2012).

Menurut zaenuri et al (2014), alternatif pemecahan yang dapat diupayakan adalah dengan membuat pakan buatan sendiri melalui teknik sederhana dengan memanfaatkan sumber-sumber bahan baku yang relatif murah. Tentu saja bahan baku yang digunakan harus memiliki kandungan nilai gizi yang baik yaitu yang mudah didapat ketika diperlukan, mudah diolah dan diproses, mengandung zat gizi yang diperlukan oleh ikan, dan berharga murah. Bahan baku murah dan 
tersedia di alam sebagai penyedia protein tinggi diantaranya adalah maggot yang berasal dari lalat BSF (black soldier fly) yang mengandung protein hewani sebesar 40-50\% (Wardhana, 2016), dan jenis tanaman lemna minor yang merupakan tanaman air yang memiliki Kandungan protein kasar $37,6 \%$ dan serat yang relatif rendah yakni 9,3\% (Culley et al. 1981).

Maggot merupakan larva dari jenis lalat dengan nama latin Hetermia illucens yang memiliki siklus hidup antara 40 hari sampai dengan 43 hari (Tomberlin dan Sheppard, 2002). Tingginya nutrisi yang terkandung pada maggot, ketersediaannya yang melimpah, pemanfaatannya yang tidak bersaing dengan manusia serta media tumbuhnya yang mudah dibuat menunjukkan potensi yang baik sebagai alternatif kombinasi pakan ikan (Fauzi dan Eka, 2018).

Lemna minor merupakan tanaman air yang tumbuh mengapung bebas dengan tingkat penyebaran yang sangat luas dan potensial sebagai sumber hijauan pakan bagi ternak yang berkualitas tinggi dengan berkembang biak secara vegetatif atau tunas (Kittiwongwattana dan Vuttipongchaikij, 2013). Tanaman ini banyak dijumpai di daerah pekalongan sehingga potensial untuk dimanfaatkan sebagai bahan baku pembuat pellet. Tujuan dari kegiatan ini adalah pemanfaatan bahan baku alami sebagai bahan alternatif penunjang pembuatan pakan ikan dengan konsep teknologi tepat guna untuk pemenuhan kebutuhan pakan ikan lele.

\section{Metode}

Tabel 1. Metode pelaksanaan

\begin{tabular}{|c|c|c|}
\hline No. & Kegiatan & Metode \\
\hline 1. & $\begin{array}{l}\text { Sosialisasi program PPTTG kepada } \\
\text { mitra POKDAKAN }\end{array}$ & Ceramah dan diskusi \\
\hline 2. & Pengenalan bahan baku & Ceramah dan diskusi \\
\hline 3. & $\begin{array}{l}\text { Pelatihan budidaya Maggot BSF } \\
\text { (larva lalat tentara hitam) }\end{array}$ & $\begin{array}{l}\text { Ceramah, praktek dan Tanya } \\
\text { jawab }\end{array}$ \\
\hline 4. & $\begin{array}{l}\text { Pelatihan budidaya tanaman Lemna } \\
\text { minor }\end{array}$ & $\begin{array}{l}\text { Ceramah, praktek dan Tanya } \\
\text { jawab }\end{array}$ \\
\hline 5. & Pembuatan demplot dan aplikasi & \multirow{2}{*}{$\begin{array}{l}\text { Uji coba, pengamatan dan } \\
\text { diskusi }\end{array}$} \\
\hline $\begin{array}{l}6 . \\
7 .\end{array}$ & $\begin{array}{l}\text { Membuat pakan buatan } \\
\text { Pendampingan untuk konsultasi }\end{array}$ & \\
\hline
\end{tabular}

Skema kegiatan PPTTG sebagai ditampilkan pada gambar 1.

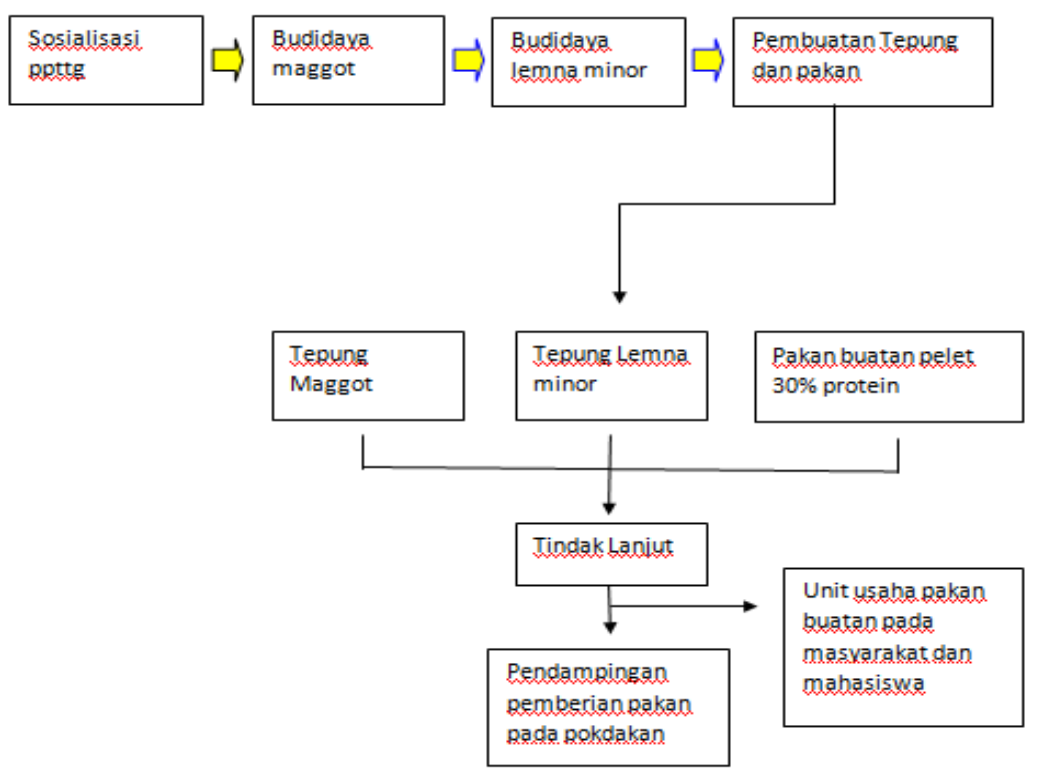

Gambar.1 Skema kegiatan PPTTG KM 2018 
Adapun metode pelaksanaan tahapan kegiatan sesuai tabel satu diatas dijelaskan sebagai berikut:

1. Sosialisasi program PPTTG tentang penggunaan pakan buatan berbasis maggot bsf dan tanaman lemna minor dengan menggunakan alat penepung model FFC-15, pembuat pellet model MPT0010 dan pengering rakitan menggunakan gas. kepada masyarakat mitra POKDAKAN di kota pekalongan dengan metode ceramah dan diskusi. Tujuan sosialisasi ini untuk memberikan gambaran tentang kegiatan ini kepada mitra pokdakan .

2. Pengenalan bahan baku yang akan digunakan sebagai bahan pokok dalam pembuatan pellet sehingga proses pembuatan dapat efektif, efisien dan berkelanjutan.

3. Pelatihan budidaya maggot BSF atau yang sering di kenal dengan lalat tentara hitam. Masyarakat POKDAKAN diharapkan mampu melakukan proses budidaya yang baik untuk mengembangkan maggot BSF mulai dari penyediaan bibit dari alam sampai pengembangan secara budidaya sehingga dapat mencukupi sebagai bahan baku pembuatan pellet.

4. Pelatihan budidaya tanaman Lemna minor untuk memberikan pembekalan bagaimana budidaya tanaman Lemna minor ini sehingga dapat berkembang dengan baik dan mendapatkan hasil yang maksimal.

5. Pembuatan demplot budidaya maggot dan tanaman lemna minor bertujuan untuk mempermudah pengenalan kegiatan kepada mitra POKDAKAN sehingga tujuan dari pelatihan dapat lebih mudah dipahami.

6. Membuat pakan buatan untuk membagi ilmu tentang proses pembuatan pellet dari bahan baku maggot dan Lemna minor.

7. Pendampingan kepada mitra berupa layanan konsultasi bila ditemui permasalahan tentang operasional alat pembuat pellet. Pendampingan dilakukan walaupun jadwal dari program pengabdian telah selesai.

\section{HASIL DAN PEMBAHASAN}

Hasil kegiatan penerapan teknologi tepat guna kepada masyarakat (PPTTG KM) adalah telah dilaksanakan pelatihan dan pendampingan proses pembuatan pellet dengan menggunakan alat pengering dan penepung bahan baku kemudian dijadikan pellet dengan menggunakan alat penepung model FFC-15, pembuat pellet model MPT0010 dan pengering rakitan menggunakan gas. Pelaksanaan proses penyediaan bahan baku maggot dilakukan mulai dari pengenalan maggot dari jenis lalat BSF (black soldier fly), memilih makanan yang tepat berupa jenis limbah organik bagi maggot sampai membuat tempat budidaya maggot sehingga mampu memberi gambaran yang mempermudah pemahaman masyarakat yang tergabung dalam mitra pokdakan.

a. Sosialisasi

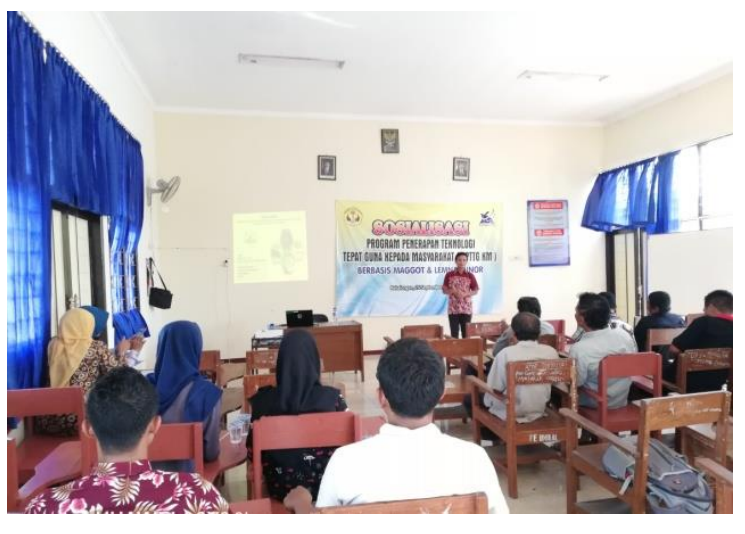

b. Budidaya maggot BSF

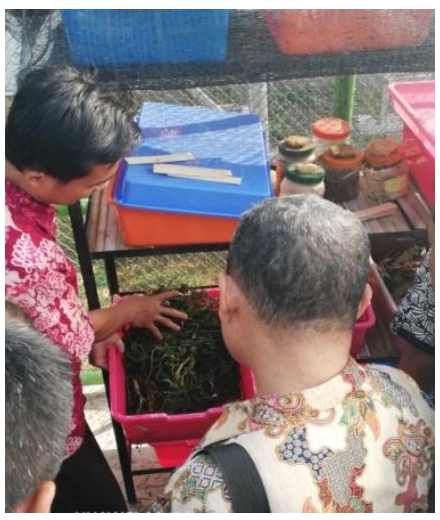

Gambar 2. a. sosialisasi kegiatan PPTTG KM, b. budidaya maggot BSF

Pelatihan dan pendampingan yang dilaksanakan dalam penyediaan bahan baku selain maggot BSF adalah penyediaan tanaman Lemna minor. Tanaman lemna minor merupakan tanaman disukai 
oleh ternak sehingga saat pelatihan diusahakan pada awal budidaya dipersiapkan tempat yang tepat dan dijauhkan dari binatang ternak. Walaupun perkembangannya cepat namun apabila di awal budidaya tidak diperhatikan perkembangannya, tanaman akan habis di makan oleh binatang ternak. Budidaya yang tepat dan ketersediaan nutrisi yang cukup membantu mempercepat perkembangan tanaman lemna. Pembuatan demplot dan penyebaran bibit bersama dengan mitra pokdakan menjadikan masyarakat mampu melaksanakan budidaya tanaman lemna minor. kegiatan ini diikuti oleh 30 peserta dari kedua mitra pokdakan. Kendala yang dihadapi dalam budidaya ini apabila terjadi rob di wilayah pokdakan, maka tanaman akan ikut hanyut atau apabila kolam budidaya airnya tercampur oleh air asin maka tanaman lemnanya akan mati sehingga harus cepat dipanen.

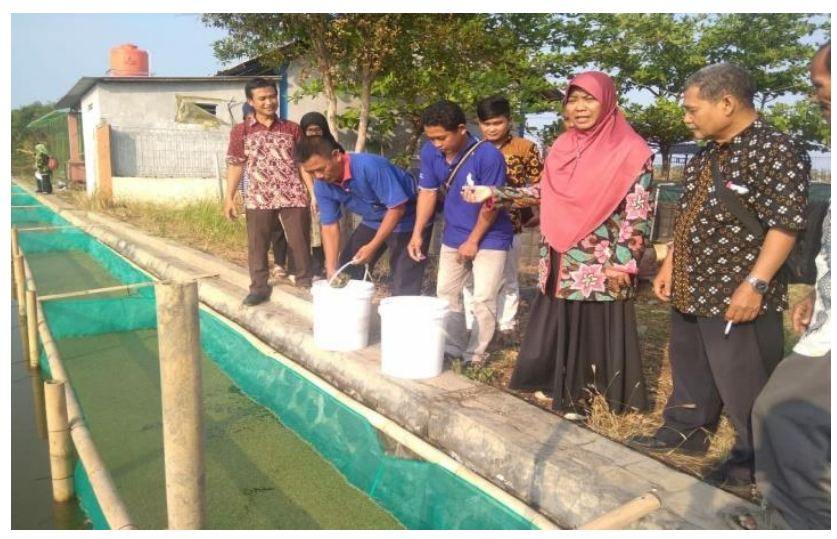

Gambar 3. Penebaran bibit tanaman lemna minor bersama mitra pokdakan

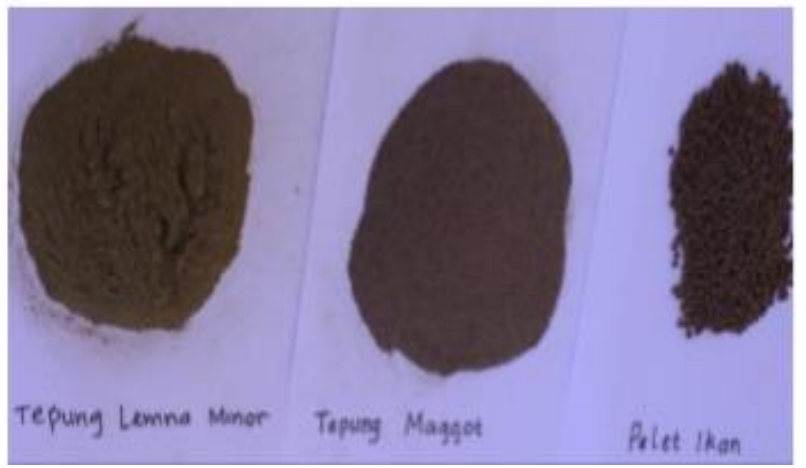

Gambar 4. Tepung lemna minor, tepung maggot dan pellet

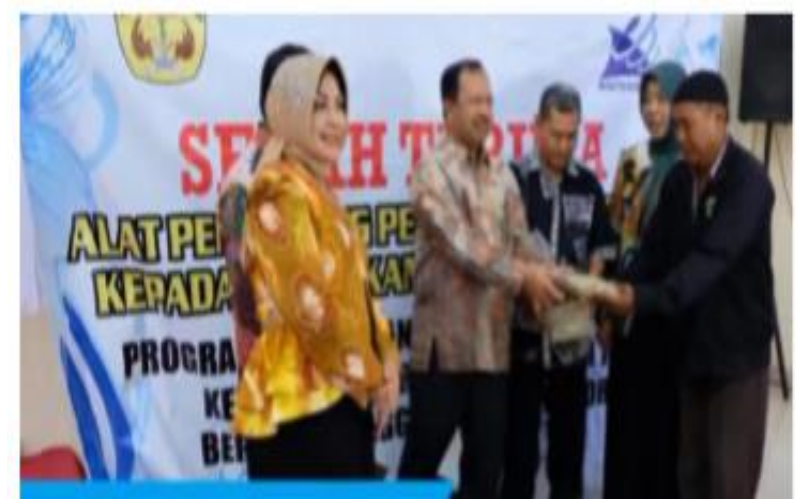

Gambar 5. Serah terima alat kepada mitra Pokdakan kepala Dirjen

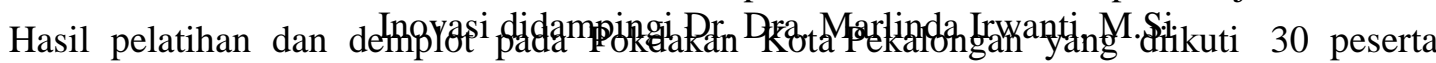
dihasilkan , $85 \%$ peserta dapat menggunakan alat penepung model ffc-15, ala dan alat pembuat 
pellet model mpt 0010 dan alat pengering menggunakan gas sehingga menghasilkan pelet untuk pakan ikan lele berbahan dasar lemna dan maggot yang bahan tersebut diproduksi sendiri. Dengan adanya bahan baku pakan yang memiliki kandungan protein tinggi mampu mengurangi biaya produksi pakan sehingga ikan lele yang dibudidaya sendiri mampu memperoleh keuntungan yang lebih dibandingkan bahan baku protein dari ikan yang berasal dari membeli di nelayan atau pabrik pengolahan ikan. Pellet yang dihasilkan diharapkan dapat dikembangkan selain untuk pokdakan sendiri juga untuk dikomersilkan dijual ke pembudidaya ikan dengan harga yang lebih rendah dari pasaran namun mutu pakan dapat terjaga.

\section{KESIMPULAN}

Kesimpulan yang dapat diperoleh dari pelaksanaan kegiatan PPTTG KM "Penggunaan Pakan Buatan berbasis Maggot dan Lemna minor pada Pokdakan di Kota Pekalongan yaitu Peserta antusias terhadap program PPTTG KM, pelatihan tersebut berdampak positif bagi pokdakan yaitu 85\% peserta mampu: a) membudidayakan maggot BSF (black soldier fly) b) membudidayakan tanaman lemna minor, c) membuat pakan buatan berbasis maggot dan lemna minor. Kemampuan tersebut diharapkan dapat membantu masyarakat dalam menyediakan pakan yang murah terjangkau dan berkelanjutan sehingga meningkatkan kesejahteraan masyarakat terutama dikalangan pokdakan di kota pekalongan.

\section{UCAPAN TERIMAKASIH}

Tim pengabdi menyampaikan ucapan terima kasih kepada Dirjen Inovasi BPPT Kemenristekdikti yang telah mendukung penuh pelaksanaan kegiatan pengabdian kepada masyarakat melalui Program penerapan teknologi tepat guna kepada masyarakat dengan no SPPK : 191/SP2h/PPM/ DRPM/2018 ini. Demikian juga terima kasih kepada LPPM Universitas Pekalongan yang telah memfasilitasi dan mendampingi tim pengabdi mulai dari perencanaan, pelaksanaan hingga proses pelaporan kegiatan. Kepada POKDAKAN mitra juga kami sampaikan terima kasih telah berperan aktif dalam pelaksanaan pengabdian yang telah dilakukan demi terlaksananya program ini, serta pihak-pihak terkait yang telah membantu hingga terlaksananya program pengabdian ini.

\section{DAFTAR PUSTAKA}

Culley DD, Rejmankova E, Kvet J, Frye JB. 1981. Production chemical quality and use of duckweeds (Lemnaceae) in aquaculture, waste management and animal feeds. J. of the Worldmariculture Society. 12(2):27-49.

Dani NP, Agung B, Shanti L,. 2005. Komposisi Pakan Buatan Untuk Meningkatkan Pertumbuhan dan Kandungan Protein Ikan Tawes (Puntius javanicus Blkr.). J. BioSMART . 7 (2): 83-90.

Fauzi, R.U.A, dan E.R.Novieta Sari. 2018. Analisis Usaha Budidaya Maggot sebagai Alternatif Pakan Lele, J. Teknologi dan Manajemen Agroindustri: 7 ( 1) 39-46

Kittiwongwattana, C and S Vuttipongchaikij. 2013. Effect of nutrient media on vegetative growth of Lemna minor and Landoltia punctata during in vitro and ex vitro cultivation. Maejo International J of Sci and Technol. 7(01):60-69

Setyono, B. 2012. Pembuatan Pakan Buatan. Unit Pengelola Air Tawar. Kepanjen. Malang.

Tomberlin, J. K., \& Sheppard, D. C. (2002). Factors influencing mating and oviposition of black soldier flies (Diptera: Stratiomyidae) in a colony. Journal of Entomological Science, 37(4), 345-352. https://doi.org/10.18474/0749- 8004-37.4.345

Wardhana AH, 2016. Black Soldier Fly (Hermetia illucens) sebagai Sumber Protein Alternatif untuk Pakan Ternak. J. WARTAZOA 26 (2): 069-078. 